\title{
The Relationship Between GPX1 Pro198Leu Manganese Superoxide Dismutase Ala16Val Variants and Obstructive Sleep Apnea Syndrome
}

\author{
GPX1 Pro198Leu ve MnSOD Ala16Val Varyantları ile Obstrüktif Uyku Apnesi \\ Sendromu Arasındaki illișki
}

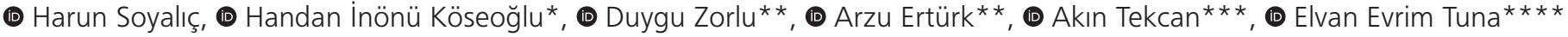 \\ Ahi Evran University Faculty of Medicine, Department of Otolaryngology, Kırşehir, Turkey \\ *Gaziosmanpaşa University Faculty of Medicine, Department of Chest Diseases, Tokat, Turkey \\ **Ahi Evran University Faculty of Medicine, Department of Chest Diseases, Kırşehir, Turkey \\ ***Amasya University Faculty of Medicine, Department of Medical Genetics, Amasya, Turkey \\ ****Ankara City Hospital, Clinic of Otolaryngology, Ankara, Turkey
}

\begin{abstract}
Objective: To investigate the association between obstructive sleep apnea syndrome (OSAS), glutathione peroxidase-1 (GPX1) Pro198Leu, and manganese superoxide dismutase (MnSOD) Ala16Val gene polymorphisms.

Materials and Methods: The study included 81 patients with OSAS and 75 healthy controls from the Turkish population. Genotypes of the MnSOD rs4880 T/C (Ala16Val) and GPX1 rs1050450 T/C (Pro198Leu) variants were determined via single-nucleotide polymorphisms genotyping analysis, which is based on simple probe melting curve analysis.

Results: The frequencies of the MnSOD rs4880 T/T, T/C, and C/C were $35.8 \%, 50.6 \%$, and $13.5 \%$ in patients with OSAS and $34.6 \%$, $49.3 \%$, and $16 \%$ in the controls, respectively. No statistically significant difference was determined between patients and controls in terms of MnSOD rs4880 variant genotype and allele distribution (odds ratio: 1.07; 95\% confidence interval: $0.68-1.69 ; \mathrm{p}>0.05)$. The frequencies of the GPX1 rs $1050450 \mathrm{~T} / \mathrm{T}, \mathrm{T} / \mathrm{C}$, and $\mathrm{C} / \mathrm{C}$ were $12.0 \%, 38.5 \%$, and $49.4 \%$ in patients with OSAS and $13.1 \%, 42.1 \%$, and $44.7 \%$ in the controls, respectively. No statistically significant difference was determined in the genotype and allele frequencies of the GPX1 rs1050450 variant between the patients and controls $(p>0.05)$. Additionally, the haplotype was examined on the basis of combined genotypes for the two variants in patients with OSAS and controls, which revealed no statistically significant correlation.

Conclusion: Our study indicates that two polymorphisms in these antioxidant enzymes were not associated with Turkish patients with OSAS. Further studies may reveal an association between these two polymorphisms with some clinical parameters in patients with OSAS.

Keywords: Gene polymorphisms, GPX1, MnSOD, obstructive sleep apnea syndrome, oxidative stress
\end{abstract}

Öz

Amaç: Bu çalışmanın amacı obstrüktif uyku apne sendromu (OUAS) ve glutatyon peroksidaz-1 (GPX1) Pro198Leu ve manganez süperoksit dismutaz (MnSOD) Ala16 Val gen polimorfizmleri arasındaki ilişkiyi araştırmaktır.

Gereç ve Yöntem: Çalışmaya OUAS'li 81 hasta ve 75 sağlıklı kontrol dahil edildi. MnSOD rs4880 T/C (Ala16Val) ve GPX1 rs1050450 T/C (Pro1 98Leu) varyantlarının genotipleri, SNP tipleme analizi ile belirlendi. Bulgular: MnSOD rs4880T/T, T/C, C/C frekansları hastalarda sırasıyla $\% 35,8, \% 50,6$ ve $\% 13,5$ ve kontrollerde $\% 34,6, \% 49,3$ ve $\% 16$ idi. Hastalar ve kontroller arasında MnSOD rs4880 varyant genotipi ve alel dağılımı açısından istatistiksel anlamlı fark saptanmadı (olasılık oranı: 1,07; \%95 güven aralığı: 0,68-1,69; p>0,05). GPX1 rs1050450T/T, T/C, C/C frekansları hastalarda sırasıyla $\% 12,0, \% 38,5$ ve $\% 49,4$ ve kontrollerde $\% 13,1, \% 42,1$ ve $\% 44,7$ idi. Hastalar ve kontrol grubu arasında GPX1 rs1050450 varyantının genotip ve alel frekanslarında anlamlı bir fark gözlenmedi $(p>0,05)$. Ayrıca OSAS hastalarında ve kontrol grubunda, iki varyant için kombine genotiplere dayanan haplotipi arasında ilişki saptanmadı.

Sonuç: Çalışmamız, GPX1 Pro198Leu, MnSOD Ala16Val gen varyantlarının OUAS ile ilişkili olmadığını göstermektedir. Illeri çalışmalar, bu iki polimorfizmin OUAS hastalarında bazı klinik parametrelerle ilişkili olduğunu ortaya çıkarabilir.

Anahtar Kelimeler: Gen polimorfizm, GPX1, MnSOD, obstrüktif uyku apne sendromu, oksidatif stres 


\section{Introduction}

Obstructive sleep apnea syndrome (OSAS) is characterized by complete or partial obstruction of the upper airway during sleep. Intermittent hypoxemia, transient hypercapnia, and frequent arousals occur in OSAS (1). OSAS is characterized by repetitive cycles of hypoxia and reoxygenation. In previous studies, it was shown that typical role of oxidative stress in patients with OSAS $(2,3)$.

If oxidation is not eliminated by antioxidant enzymes in cells, oxidative stress occurs. In fact, there is a balance between oxidant and antioxidant reactions in the human body. Increased production of reactive oxygen species (ROS) or an organism's reduced ability to counteract ROS through antioxidant enzymes may lead to OS. ROS are highly aggressive and therefore, induce lipid peroxidation and DNA damage $(4,5)$.

Although OS occurs in all individuals, some of them are more prone to damage caused by OS. Genetic factors such as polymorphisms in genes of antioxidant enzymes may affect the individual defense response against $O S$ and subsequent pathology (6). Antioxidant enzymes provide cell defense against OS. Glutathione peroxidase-1 (GPX1) and manganese superoxide dismutase (MnSOD) are among these enzymes. The gene encoding MnSOD has five exons on chromosome $6 q 25$ (7). A well-known polymorphism of MnSOD is the Ala16 Val polymorphism, which is replacement of GCT with GTT. This polymorphism affects the conformation of the leader signal of MnSOD and diminishes the localization of MnSOD to mitochondria $(8,9)$. GPX1 is the most abundant isoform of glutathione peroxidase and has a role in antioxidant activity of the cell $(10,11)$. GPX1 eliminates peroxides by converting them into water and alcohol (12). One of the polymorphisms in the GPX-1 gene is found at codon 198 (C to T); this leads to the replacement of proline (CCC) with leucine (CTC). The amino acid substitution affects the structural conformation of the active site region and leads a reduction in the enzyme activity (13). The Pro198Leu variant of this enzyme has been shown to cause a $40 \%$ reduction in the enzyme activity (14).

Since there is an association between OSAS and OS, we suggested that there may be an association between OSAS and the two polymorphisms in two antioxidant enzymes, namely the GPX1 Pro198Leu and MnSOD Ala16Val variants. These two polymorphisms may play a relevant role in the oxidative stress in OSAS patients.

\section{Materials and Methods}

\section{Subjects}

Eighty-one patients with OSAS were included in the study group (50 males and 31 females), and 75 (44 males and 31 females) healthy controls were enrolled. Subjects recruited for the study were over 18 years of age. Patients were excluded on the basis of having a genetic syndrome, mental retardation, and central sleep apnea syndrome. Subjects with systemic disease, chronic inflammatory or autoimmune disorders, and cancers were excluded from this study. Informed written consent was obtained from all subjects before enrollment to the study.
The study was performed according to the Declaration of Helsinki, and was approved by the Ahi Evran University Faculty of Medicine Clinical Research Ethics Committee (approval no: 201-15/177).

\section{Polysomnography monitoring}

To objectively determine the night sleeping status of each participant, polysomnography was carried out by the in-laboratory Philips Respironics Alice 5, 2016, USA device using the American Academy of Sleep Medicine 2007 criteria. The polysomnography scoring was calculated automatically by the computer software and controlled by the experienced pulmonologist in sleep medicine. The patient group was divided into mild-moderate OSAS and severe OSAS.

\section{Genotype analysis}

To determine genotypes of the MnSOD rs4880 T/C and GPX1 rs1050450 T/C (Pro198Leu) missense variants in OSAS cases and healthy controls, SNP typing analysis (LightSNIP; Tib-MolBiol, Berlin, Germany) were carried out. The analysis was attribute to simple probe melting curve analysis, which was utilized to detect GPX1 (rs1050450) and SOD2 (rs4880) polymorphisms. On the Roche Light Cycler 480 II platform, polymerase chain reaction (PCR) and melting curve analyses were conducted. The reaction for each SNP was performed in a final volume of $20 \mu \mathrm{L}$ and included $2 \mu \mathrm{L}$ DNA, $1 \mu \mathrm{L}$ LightSNIP reagent mix (Tib-MolBiol), $2 \mu \mathrm{L}$ LightCycler FastStart DNA Master HybProbe (Roche Diagnostics $\mathrm{GmbH}$, Mannheim, Germany), $1.6 \mu \mathrm{L} \mathrm{MgCl}_{2}(25 \mathrm{mM})$, and $14.4 \mu \mathrm{L} \mathrm{H}$ O. The PCR consisted of a denaturation step at $95{ }^{\circ} \mathrm{C}$ for 10 minutes at 45 cycles, a denaturation at $95{ }^{\circ} \mathrm{C}$ for 10 seconds, an annealing step at $60{ }^{\circ} \mathrm{C}$ for 10 seconds, and elongation at $72{ }^{\circ} \mathrm{C}$ for 15 seconds, respectively. After the last cycle, samples were held at $95{ }^{\circ} \mathrm{C}$ for 30 seconds before the temperature was lowered to $45{ }^{\circ} \mathrm{C}$. Next, melting was conducted by steadily raising the temperature in $0.5{ }^{\circ} \mathrm{C}$ increments every 2 seconds from $45^{\circ} \mathrm{C}$ to $75{ }^{\circ} \mathrm{C}$.

\section{Statistical Analysis}

The statistical analyses were done by SPSS Statistical Program Version 21.0 and Openepi 3.01 software package programs. Continuous data were given as mean \pm standard deviation and (minimum-maximum). A chi-square test was utilized to analyze the significance differences in the allele frequency and genotype distribution between the two study groups. A Hardy-Weinberg equilibrium test was done for both study groups.

\section{Results}

Demographic and clinical characteristics of the cases and control subjects in the studied population are shown in Table 1. In OSAS patients, the mean age was $52.20 \pm 11.17$ years. In healthy controls, the mean age was $45.48 \pm 11.65$. The male/female ratio was $61.72 / 38.27 \%$ in patients with OSAS and $58.66 / 41.33 \%$ in controls. Table 2 shows the MnSOD rs4880 T/C and GPX1 rs1050450 T/C (Pro198Leu) variants genotype and allele distribution. The frequencies of the MnSOD rs4880T/T, T/C, C/C were $35.8 \%, 50.6 \%$, and 
$13.5 \%$ in patients and $34.6 \%, 49.3 \%$, and $16 \%$ in controls, respectively. The frequency of the $\mathrm{T}$ allele in patient cases was $61.1 \%$ and $59.3 \%$ in the healthy control group. Statistically significant differences were not found between OSAS patients and healthy controls with respect to the MnSOD rs4880 variant genotype and allele distribution [odds ratio (OR): 1.07; 95\% confidence interval (Cl): 0.68-1.69; $\mathrm{p}>0.05$ ] (Table 2). The frequencies of the GPX1 rs1050450T/T, T/C, C/C were $12.0 \%, 38.5 \%$, and $49.4 \%$ in patients and $13.1 \%, 42.1 \%$, and $44.7 \%$ in controls, respectively. The frequency of the T allele in patient cases was $31.3 \%$ and $34.2 \%$ in the healthy control group. We observed no significant differences in the genotype and allele frequencies of GPX1 rs1050450 variant between OSAS patients and controls (OR: 0.87; 95\% Cl: 0.54-1.40; $\mathrm{p}>0.05$ ) (Table 2). We also examined the haplotype analysis based on the combined genotypes for the two variants in OSAS patients and healthy controls using the Haploview software (version 4.2) (Table 3). Compared to control group, there was no statistically significant difference between OSAS and the different haplotypes of MnSOD rs4880 T/C and GPX1 rs1050450 T/C.

\begin{tabular}{|c|c|c|}
\hline Characteristics & Control group & OSAS group \\
\hline Gender, male/female (n) & $44 / 31$ & $50 / 31$ \\
\hline Age, mean $\pm S D$, years & $45.48 \pm 11.65$ & $52.20 \pm 11.17$ \\
\hline $\mathrm{BMI}\left(\mathrm{kg} / \mathrm{m}^{2}\right)$, mean $\pm \mathrm{SD}^{*}$ & $24.97 \pm 3.12$ & $34.87 \pm 6.04$ \\
\hline $\mathrm{AHI}$ (events/h), mean $\pm S D^{\star *}$ & $3 \pm 2$ & $44 \pm 23$ \\
\hline $\begin{array}{l}\text { Mild-moderate sleep apnea } \\
\text { Severe sleep apnea }\end{array}$ & $\begin{array}{l}- \\
-\end{array}$ & $\begin{array}{l}24(38.7 \%) \\
38(61.3 \%)\end{array}$ \\
\hline \multicolumn{3}{|c|}{$\begin{array}{l}\text { OSAS: Obstructive sleep apnea syndrome, } n: \text { Number of subjects, SD: Standarc } \\
\text { deviation, BMI: Body mass index, AHI: Apnea-hypopnea index, }{ }^{*} p<0.05 \text {, } \\
{ }^{* \star} p<0.01\end{array}$} \\
\hline
\end{tabular}

\section{Discussion}

Cycles of hypoxia and reoxygenation is one of the characteristics of OSAS, and these cycles of hypoxia lead to the production of ROS and OS. There are OS markers consistently associated with OSAS such as malondialdehyde and antioxidant enzyme superoxide dismutase (SOD) (15). Since antioxidant enzymes were found to be associated with OSAS, we intended to research the association of polymorphisms in two antioxidant enzymes, GPX1 and MnSOD, with OSAS. We studied the frequencies of GPX1 Pro1 98Leu (rs1050450 T/C variant) and MnSOD Ala16Val (rs4880 T/C variant) variants in 81 patients with OSAS and 75 healthy controls. We found that these antioxidant enzyme gene polymorphisms in OSAS patients were not statistically significant difference from healthy people.

In a study, serum markers for OS in OSAS patients were investigated, and patients with severe OSAS were shown to have significantly lower serum levels of two important antioxidant enzymes, catalase and GPx. Serum malondialdehyde levels were also higher in OSAS group (16). Repeated cycles of hypoxia in OSAS patients alter arterial oxygen saturation, and this situation may induce the production of ROS (17). The release of ROS in these patients may damage the vascular endothelium, which may be the underlying mechanism for cardiovascular morbidities in OSAS patients (18). Others have also reported the increase of OS markers in OSAS patients $(19,20)$. Lavie et al. (20) reported that compared to controls, the levels of thiobarbituric reactive substances (TBARS) and peroxides (PD) were higher in OSAS patients. In addition, there was a negative correlation between the respiratory disturbance index (RDI) and the antioxidant protective enzyme paraxonase-1. Conversely, there was a positive correlation between concentrations of TBARS and PD and RDI in OSAS patients. Moreover, there was a tendency of decreased paraxonase-1 in OSA patients with cardiovascular disease. These results strongly suggest that OS and OS markers are increased in OSAS patients, and the degree

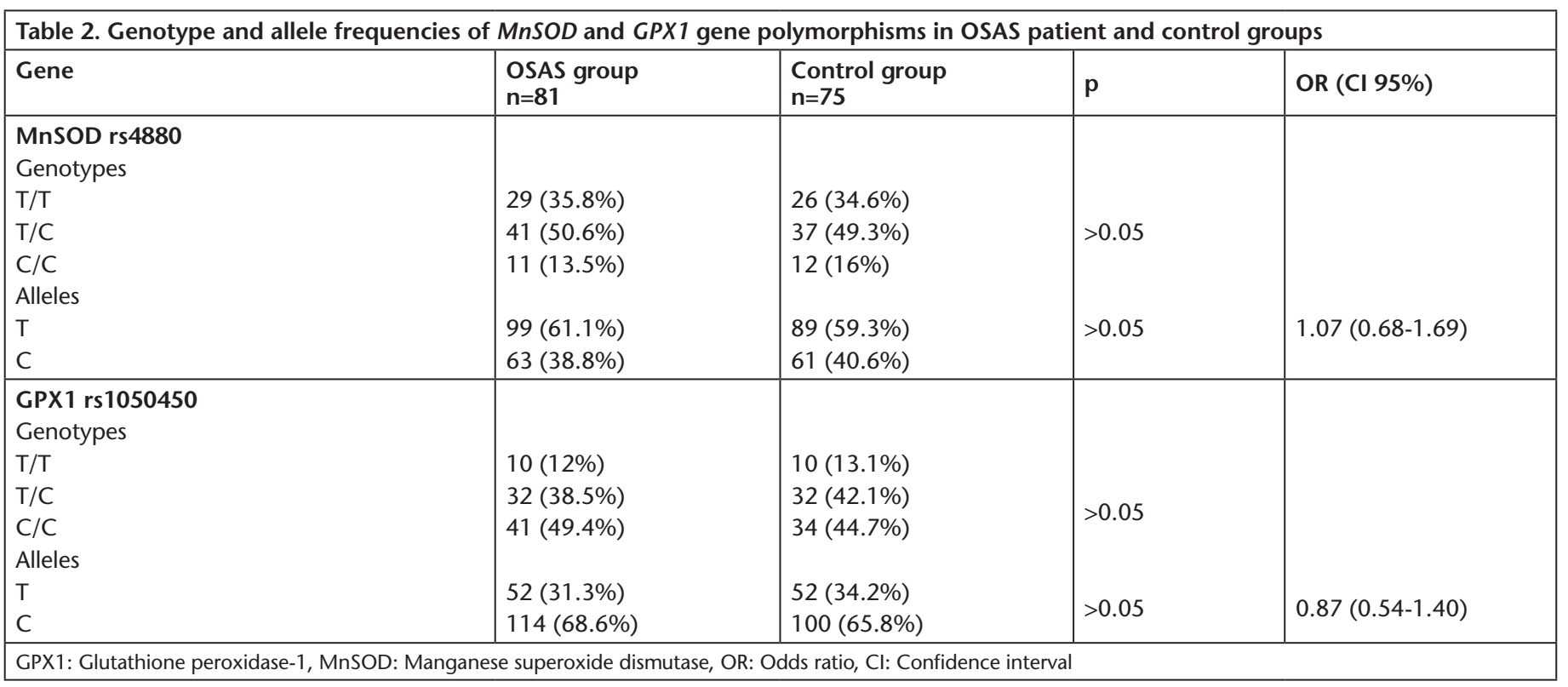


Soyalıç et al.

Obstructive Sleep Apnea and Antioxidant Enzyme Gene Polymorphism

\begin{tabular}{|c|c|c|c|c|c|}
\hline \multirow[t]{2}{*}{ Genotypes } & \multicolumn{2}{|c|}{ Patients $(n=81)$} & \multicolumn{2}{|c|}{ Control $(n=75)$} & \multirow[t]{2}{*}{$p$} \\
\hline & $\mathrm{n}$ & $\%$ & $n$ & $\%$ & \\
\hline \multicolumn{6}{|c|}{ SOD2 rs4880 T/C-GPX1 rs1050450 T/C } \\
\hline$\pi-\pi$ & 3 & 3.7 & 5 & 6.6 & \multirow{9}{*}{$>0.05$} \\
\hline TT-TC & 11 & 13.5 & 12 & 16 & \\
\hline TT-CC & 15 & 18.5 & 9 & 12 & \\
\hline TC-TT & 4 & 4.9 & 3 & 4 & \\
\hline TC-TC & 17 & 20.9 & 15 & 20 & \\
\hline TC-CC & 20 & 24.6 & 19 & 25.3 & \\
\hline CC-TT & 3 & 3.7 & 2 & 2.6 & \\
\hline CC-TC & 4 & 4.9 & 4 & 5.3 & \\
\hline CC-CC & 4 & 4.9 & 6 & 8 & \\
\hline
\end{tabular}

of OS in OSAS patients correlate with comorbidities observed in these patients. Sales et al. (21) showed that antioxidant levels were lower in patients with OSAS. The patients had decreased amounts of vitamin E, superoxide dismutase, and vitamin B11. They found that these values might correlate with impaired cognitive function in these patients.

Several SNPs were associated with OSAS. The C haplotype of rs5417 in glucose transporter 4 gene was shown to be associated with OSAS in Chinese population (22). The frequencies of minor alleles of the IL-10 gene promoter polymorphisms were higher in Turkish population with OSAS, and ATA haplotype of three polymorphisms in IL-10 gene promoter was significantly higher in OSAS patients (23). Bhushan et al. (24) compared two obese groups with or without OSAS ( $\mathrm{n}=207$ individuals) and showed that the A allele of TNF-alpha gene promoter polymorphism (-308G/A) was higher in obese individuals with OSAS compared to obese individuals without OSAS $(28.8 \%$ vs. $12.6 \%)$. Furthermore, serum TNF-alpha values were higher in patients with OSAS (24). Based on this study, SNPs in the gene regions of inflammatory players such as IL-10 and TNF-alpha are associated with OSAS. At the same time, it was shown that OS stress causes the activation of inflammatory cascade in patients with OSAS. This might be associated with comorbidities such as cardiovascular diseases observed in patients with OSAS $(25,26)$. Therefore, SNPs in antioxidant enzyme genes might be associated with OSAS as SNPs in inflammatory genes were associated with OS and inflammation in patients with OSAS. This concept was one of the reasons that made us to hypothesize that there might be SNPS in GPX1 and MnSOD genes associated with OSAS.

Since there is an association between OSAS and OS, it was expected that there were polymorphisms of oxidant and antioxidant enzyme genes linked to OSAS. There are reports indicating an association between these types of enzymes and OSAS. OS may be caused by over-generation of ROS. The major source of ROS in the vasculature are the NADPH oxidases (27). The $G$ allele of A-930G polymorphism in the gene region of the p22phox subunit of NADPH oxidases was found to be associated with OSAS (28). The paraoxonase-1
$(P O N-1)$ gene L55M polymorphism and enzyme activity were investigated in patients with OSAS and controls. PON1 gene L55M polymorphism frequency was significantly different between patients with OSA and controls, and the paraoxonase activity of the enzyme was lower in patients $(29,30)$.

GPX1 and MnSOD are critical antioxidant enzymes in the control of ROS. Genetic variants of these enzymes especially GPX1 Pro198Leu and MnSOD Ala16Val have been implicated in various diseases. It was found that the $\mathrm{Val} / \mathrm{Val}$ genotype ( $\mathrm{T} / \mathrm{T}$ ) of MnSOD was higher in men in patients with coronary heart disease (CHD) compared to controls (39.18\% vs. $22.69 \%$ ). Males with this genotype were almost at two-fold risk of CHD. However, in this study, there was no association between Pro198Leu GPx polymorphism to CHD risk (31). Ischemic stroke (IS) risk was shown to be nearly four-fold higher in patients carrying the Val allele of MnSOD compared to ones with the Ala allele. On the other hand, GPX1 Pro193Leu was not found to be a risk factor for IS (32). Studies imply that GPX1 and MnSOD could have a protective role against atherosclerosis $(33,34)$. In another study, there was an association between vascular complications of diabetes mellitus and MnSOD Ala16Val polymorphism (35). Kangas-Kontio et al. (36) showed that the MnSOD Ala16Val polymorphism is associated with diabetic retinopathy (36). The GPx1 Pro198Leu polymorphism has been found to be associated with bladder cancer. Coexistence of MnSOD Ala/Ala genotype with GPX1 Leu/Leu genotype had a synergistic effect on risk of disease (37). In several studies GPx1 Pro198Leu polymorphism was shown to be linked breast and lung cancer, coronary heart disease, and diabetic peripheral neuropathy (38-41). There are several limitations of our study. Our study sample is relatively small. In addition, inclusion and analysis of a higher number clinical parameters and serum parameters would make it possible to correlate studied SNPs, and those clinical parameters.

\section{Conclusion}

We suggested that there might be a link between polymorphisms of two antioxidant genes, GPx1 and MnSOD, since OS was strongly implicated in patients with OSAS. However, we found 
that these two antioxidant enzyme gene polymorphisms were not statistically significant compared to healthy individuals without OSAS. Further studies may be performed in order to find out whether these two polymorphisms have an association with some clinical parameters or serum markers in OSAS patients.

\section{Ethics}

Ethics Committee Approval: The study was performed according to the Declaration of Helsinki, and was approved by the Ahi Evran University Faculty of Medicine Clinical Research Ethics Committee (approval no: 201-15/177).

Informed Consent: Informed written consent was obtained from all subjects before enrollment to the study.

Peer-review: Externally and internally peer-reviewed.

\section{Authorship Contributions}

Concept: H.S., H.I.K., E.E.T., Design: D.Z., Data Collection or Processing: H.S., H.I.K., D.Z., A.E., A.T., Analysis or Interpretation: H.S., H.I.K., D.Z., A.E., A.T., E.E.T., Writing: H.S., H.I.K., D.Z., E.E.T.

Conflict of Interest: No conflict of interest was declared by the authors.

Financial Disclosure: The authors declared that this study received no financial support.

\section{References}

1. Azagra-Calero E, Espinar-Escalona E, Barrera-Mora JM, LlamasCarreras JM, Solano-Reina E. Obstructive sleep apnea syndrome (OSAS). Review of the literature. Med Oral Patol Oral Cir Bucal 2012; 17:925-9.

2. Barceló A, Miralles C, Barbé F, Vila M, Pons S, Agustí AG. Abnormal lipid peroxidation in patients with sleep apnoea. Eur Respir J 2000;16:644-7.

3. Lavie L. Oxidative stress-a unifying paradigm in obstructive sleep apnea and comorbidities. Prog Cardiovasc Dis 2009;51:303-12.

4. Collins AR. Investigating oxidative DNA damage and its repair using the comet assay. Mutat Res 2009;681:24-32.

5 Cooke MS, Evans MD, Dizdaroglu M, Lunec J. Oxidative DNA damage: mechanisms, mutation, and disease. FASEB J 2003;17:1195-214.

6. Forsberg $\mathrm{L}$, de Faire U, Morgenstern R. Oxidative stress, human genetic variation, and disease. Arch Biochem Biophys 2001;389:84-93.

7. Church SL, Grant JW, Meese EU, Trent JM. Sublocalization of the gene encoding manganese superoxide dismutase (MnSOD/SOD2) to $6 \mathrm{q} 25$ by fluorescence in situ hybridization and somatic cell hybrid mapping. Genomics 1992;14:823-5.

8. Sutton A, Khoury H, Prip-Buus C, Cepanec C, Pessayre D, Degoul F. The Ala16Val genetic dimorphism modulates the import of human manganese superoxide dismutase into rat liver mitochondria. Pharmacogenetics 2003;13:145-57.

9. Zelko IN, Mariani TJ, Folz RJ. Superoxide dismutase multigene family: a comparison of the CuZn-SOD (SOD1), Mn-SOD (SOD2), and ECSOD (SOD3) gene structures, evolution, and expression. Free Radic Biol Med 2002;33:337-49.

10. Beckett GJ, Arthur JR. Selenium and endocrine systems. J Endocrinol 2005; 184:455-65.

11. Forgione MA, Weiss N, Heydrick S, Cap A, Klings ES, Bierl C, Eberhardt RT, Farber HW, Loscalzo J. Cellular glutathione peroxidase deficiency and endothelial dysfunction. Am J Physiol Heart Circ Physiol 2002;282:1255-61.
12. Arthur JR. The glutathione peroxidase. Cell Mol Life Sci 2000;57:1825-35

13. Ratnasinghe D, Tangrea JA, Andersen MR, Barrett MJ, Virtamo J, Taylor PR, Albanes D. Glutathione peroxidase codon 198 polymorphism variant increases lung cancer risk. Cancer Res 2000;60:6381-3.

14. Jablonska E, Gromadzinska J, Reszka E, Wasowicz W, Sobala W, Szeszenia-Dabrowska N, Boffetta P. Association between GPx1 Pro198Leu polymorphism, GPx1 activity and plasma selenium concentration in humans. Eur J Nutr 2009;48:383-6.

15. Lira $A B$, de Sousa Rodrigues CF. Evaluation of oxidative stress markers in obstructive sleep apnea syndrome and additional antioxidant therapy: a review article. Sleep Breath 2016;204:1155-60.

16. Asker S, Asker M, Sarikaya E, Sunnetcioglu A, Aslan M, Demir H. Oxidative stress parameters and their correlation with clinical, metabolic and polysomnographic parameters in severe obstructive sleep apnea syndrome. Int J Clin Exp Med 2015;8:11449-55.

17. Ntalapascha M, Makris D, Kyparos A, Tsilioni I, Kostikas K, Gourgoulianis K, Kouretas D, Zakynthinos E. Oxidative stress in patients with obstructive sleep apnea syndrome. Sleep Breath 2013;17:549-55.

18. Kang IG, Jung JH, Kim ST. The effect of obstructive sleep apnea on DNA damage and oxidative stress. Clin Exp Otorhinolaryngol 2013;6:68-72.

19. Carpagnano GE, Kharitonov SA, Resta O, Foschino-Barbaro MP, Gramiccioni E, Barnes PJ. 8-Isoprostane, a marker of oxidative stress, is increased in exhaled breath condensate of patients with obstructive sleep apnea after night and is reduced by continuous positive airway pressure therapy. Chest 2003;124:1386-92.

20. Lavie L, Vishnevsky A, Lavie P. Evidence for lipid peroxidation in obstructive sleep apnea. Sleep 2004;27:123-8.

21. Sales LV, Bruin VM, D'Almeida V, Pompéia S, Bueno OF, Tufik S, Bittencourt L. Cognition and biomarkers of oxidative stress in obstructive sleep apnea. Clinics (Sao Paulo) 2013;68:449-55.

22. Yin T, Li NF, Heizhati M, Zhang J, Zhang J, Zhou L, Chang G. Association of glucose transporter 4 genetic polymorphisms with obstructive sleep apnea syndrome in Han Chinese general population: a cross-section study. Lipids Health Dis 2014;13:12. doi: 10.1186/1476-511X-13-12

23. Özdaş S, Özdaş T, Acar M, Erbek SS, Köseoğlu S, Göktürk G, Izbirak A. Association of Interleukin-10 gene promoter polymorphisms with obstructive sleep apnea. Sleep Breath 2016;20:855-66.

24. Bhushan B, Guleria R, Misra A, Luthra K, Vikram NK. TNF-alpha gene polymorphism and TNF-alpha levels in obese Asian Indians with obstructive sleep apnea. Respir Med 2009;103:386-92.

25. de Lima FF, Mazzotti DR, Tufik S, Bittencourt L. The role inflammatory response genes in obstructive sleep apnea syndrome: a review. The role inflammatory response genes in obstructive sleep apnea syndrome: a review. Sleep Breath 2016;20:331-8.

26. Lavie L, Lavie P. Molecular mechanisms of cardiovascular disease in OSAHS: the oxidative stress link. Eur Respir J 2009;33:1467-84.

27. Griendling KK, Sorescu D, Ushio-Fukai M. NAD(P)H oxidase: role in cardiovascular biology and disease. Circ Res 2000;86:494-501.

28. iérola J, Alemany $A$, Yañez $A$, de-la-Peña $M$, Sánchez-de-la-Torre $M$, Esquinas C, Pérez-Gutierrez C, Burguera B, Barbé F, Barceló A. NADPH oxidase p22phox polymorphisms and oxidative stress in patients with obstructive sleep apnoea. Respir Med 2011;105:1748-54.

29. Jaouad L, de Guise C, Berrougui H, Cloutier M, Isabelle M, Fulop T, Payette $H$, Khalil A. Age-related decrease in high-density lipoproteins antioxidant activity is due to an alteration in the PON1's free sulfhydryl groups. Atherosclerosis 2006;185:191-200.

30. Płóciniczak A, Baszczuk A, Ludziejewska A, Winiarska $H$, Michalak S, Kasprzak G, Formanowicz D, Cofta S, Wysocka E. Paraoxonase 1 
Gene L55M Polymorphism and Paraoxonase 1 Activity in Obstructive Sleep Apnea Patients. Adv Exp Med Biol 2019;1150:17-24.

31. Souiden $Y$, Mallouli $H$, Meskhi $S$, Chaabouni $Y$, Rebai $A$, Chéour $F$, Mahdouani K. MnSOD and GPx1 polymorphism relationship with coronary heart disease risk and severity. Biol Res 2016;49:22.

32. Karahalil B, Elkama A, Orhan G. Oxidative stress gene polymorphisms may have an impact in the development of ischemic stroke. J Gene Med 2017;19. doi: 10.1002/jgm.2947

33. Espinola-Klein C, Rupprecht HJ, Bickel C, Schnabel R, Genth-Zotz S, Torzewski M, Lackner K, Munzel T, Blankenberg S; AtheroGene Investigators. Glutathione peroxidase-1 activity, atherosclerotic burden, and cardiovascular prognosis. Am J Cardiol 2007;99:808-12.

34. Matarin M, Brown WM, Dena H, Britton A, De Vrieze FW, Brott TG, Brown RD Jr, Worrall BB, Case LD, Chanock SJ, Metter EJ, Ferruci L, Gamble D, Hardy JA, Rich SS, Singleton A, Meschia JF. Candidate gene polymorphisms for ischemic stroke. Stroke 2009;40:3436-42.

35. Flekac M, Skrha J, Hilgertova J, Lacinova Z, Jarolimkova M. Gene polymorphisms of superoxide dismutases and catalase in diabetes mellitus. BMC Med Genet 2008;9:30. doi: 10.1186/1471-2350-9-30

36. Kangas-Kontio T, Vavuli S, Kakko SJ, Penna J, Savolainen ER, Savolainen MJ, Liinamaa MJ. Polymorphism of the manganese superoxide dismutase gene but not of vascular endothelial growth factor gene is a risk factor for diabetic retinopathy. $\mathrm{Br}$ J Ophthalmol 2009;93:1401-6.

37. Kucukgergin C, Sanli O, Amasyalı AS, Tefik T, Seckin S. Genetic variants of MnSOD and GPX1 and susceptibility to bladder cancer in a Turkish population. Med Oncol 2012;29:1928-34.

38. Méplan C, Dragsted LO, Ravn-Haren G, Tjønneland A, Vogel U, Hesketh J. Association between polymorphisms in glutathione peroxidase and selenoprotein $\mathrm{P}$ genes, glutathione peroxidase activity, HRT use and breast cancer risk. PLoS One 2013;8:e73316.

39. Raaschou-Nielsen O, Sørensen M, Hansen RD, Frederiksen K, Tjønneland A, Overvad K, Vogel U. GPX1 Pro198Leu polymorphism, interactions with smoking and alcohol consumption, and risk for lung cancer. Cancer Lett 2007;247:293-300.

40. Tang TS, Prior SL, Li KW, Ireland HA, Bain SC, Hurel SJ, Cooper JA, Humphries SE, Stephens JW. Association between the rs 1050450 glutathione peroxidase-1 $(\mathrm{C}>\mathrm{T})$ gene variant and peripheral neuropathy in two independent samples of subjects with diabetes mellitus. Nutr Metab Cardiovasc Dis 2012;22:417-25.

41. Ye H, Li X, Wang L, Liao Q, Xu L, Huang Y, Xu L, Xu X, Chen C, Wu H, Le $Y$, Liu Q, Ye M, Dong C, Duan S. Genetic associations with coronary heart disease: meta-analyses of 12 candidate genetic variants. Gene 2013;531:71-7. 